Costa Rica in the political turmoil of central America provides an example of Dr Dyer's argument for social versus military expenditures. Costa Rica has been demilitarised since 1949. Although without many natural resources, it enjoys health, educational and economic indicators equal to many European countries. There is a clear cause-effect relationship between socioeconomic injustice, poor health and educational standards and militarisation in less developed countries. A further indicator of this phenomenon in the developed nations is that Japan and West Germany, virtually demilitarised since World War 2, have dominated the world economically.

The problem of deterrence is that a nuclear weapon 'exchange' would be an Armageddon for all-the ultimate pyrrhic victory. What deterrent value does Mutual Assured Destruction (MAD) have on NATO's defence policy? Is Dr Deary assured by the thought that obliteration of the 'enemy' will follow or precede his own demise in a nuclear war? In using the analogy of the 'bighorn sheep', Dr Deary again exposes himself as a pre-nuclear thinker-the bighorn sheep will not survive a nuclear war either.

On deterrence Dr Deary adds- "If we tamper with it, we risk lighting the fuse of a time bomb". If we do not tamper with it, with the advent of launch-on-warning systems etc., it will light its own fuse. The mystique of such matters has left deterrence in militarist thinking, hence our present dilemma. Dr Deary knows as a psychologist that it is healthier to be in control of one's life-helplessness leads to depression.

Dr Deary castigates Dr Dyer for not using intellectual arguments to support his plan; he misses the pointdeterrence has no rational basis. It is based on primitive instinctual emotions which served our ancestors well, but now threaten our very existence. We cannot afford to express our aggression with nuclear weapons. Dr Deary's defence of deterrence demonstrates denial, sanitary language use and the irrationality of military pre-nuclear thinking.

It will take more than intellectual argument to deal with this problem. It will take moral outrage of $90 \%$ of the world's population who live outside the superpowers to end this menace. The possession of nuclear weapons alone is a crime against humanity, the stockpiling of weapons of genocide.

Dr Bernard Lown summed up the scenario where we now find ourselves:- "We physicians, guardians of health and life, have an ethical categorical imperative to expose the bleak immorality of the policy of deterrence. We must not acquiesce to stockpiling weapons of mass extermination as the guarantors of national security. We must not permit the search for peace to proceed through overt flirtation with death. There are no conceivable circumstances which can justify the use of genocidal weapons".

St Stephen's Hospital

Cork, Ireland

Patrick COLL
Rererences

${ }^{2}$ Deary, I. (1986) The wisdom of deterrence-a reply to Jim Dyer Bullet in of the Royal College of Psychiatrists, 10, 165-168.

${ }^{2}$ DYer, J. (1986) The paychopathology of nuclear war. Bulletin of the Royal College of Psychiatrists, 10, 2-5.

3Einstein, Alabrt (1947) In 'Ideas and Opinions' New York: Bondage Books.

${ }^{4}$ Lown, B. (1986) The Urgency of Moral Outrage. Address given at 6th Congress IPPNW, Cologne, June 1986.

\section{ECT given to people with pacemakers}

DeAr Sirs

I have recently been faced with having to arrange ECT for a man of 72 who was depressed and who was fitted with a cardiac pacemaker. I naturally informed our local anaesthetist and she was anxious about this and got in touch with the physician who had inserted the pacemaker. He, too, was concerned about the safety of ECT under these circumstances and hesitated about giving the go-ahead for it until he had seen the gentleman himself.

I got in touch with Dr J. Pippard and he was able to provide one reference to ECT given to a person with a pacemaker. There do not appear to be many references in the literature but I have taken soundings in our Region and it appears that several psychiatrists have had experience of administering ECT to people with pacemakers. However, it is probable that there have been one or two in most psychiatrists' experience but that nobody has had many patients who have had a depression severe enough to require ECT whilst also having a pacemaker fitted.

The gentleman referred to has done very well and I would be interested to hear from other people as to whether they have had problems or a satisfactory result from such treatment. I am well aware that there are different types of pacemakers and that this is a factor in the safety of the treatment. If anybody would care to write to me to give me information on their experiences, I would be extremely grateful.

Fermoy Unit

D. H. MORGaN

Queen Elizabeth Hospital

King's Lynn PE30 4ET

\section{Mental Health Review Tribunals \\ DeAr Sirs}

We had four Mental Health Review Tribunals here this week. All were compulsory referrals; three of the four patients refused to appear before the Tribunal. Is that a record?

Glenside Hospital

R. W. K. ReEves

Stapleton, Bristol 